\title{
Copper supply during the Final Neolithic at the Saint-Blaise/ Bains des Dames site (Neuchâtel, Switzerland)
}

\author{
Florence Cattin • Igor M. Villa • Marie Besse
}

Received: 31 March 2009/Accepted: 21 August 2009/Published online: 2 October 2009

(C) Springer-Verlag 2009

\begin{abstract}
The Saint-Blaise/Bains des Dames stratified site in Neuchâtel, Switzerland, contains several occupations that span the Late through Final Neolithic, including the Horgen, Lüscherz, and Auvernier-Cordé periods. As part of a study on prehistoric metallurgy in western Switzerland, we compare the lead isotope ratios (multicollector inductively coupled plasma mass spectrometer) and elemental compositions (instrumental neutron activation analysis) of the site's numerous copper finds to a database of corresponding measurements for copper ores throughout Europe. The results show a considerable variation in copper compositions present at the site, suggesting complex economic relationships and multiple chaînes opératoires
\end{abstract}

F. Cattin $\cdot$ M. Besse

Laboratory of Prehistoric Archaeology and Human Peopling,

Department of Anthropology and Ecology, University of Geneva,

Case postale,

1211 Geneva 4, Switzerland

M. Besse

e-mail: marie.besse@unige.ch

F. Cattin $(\bowtie)$

Département d'Anthropologie, Université de Montréal,

C.P. 6128 , Succursale Centre-Ville,

Montreal, Quebec H3C 3J7, Canada

e-mail: mail@florencecattin.com

I. M. Villa

Institut für Geologie, Universität Bern,

Baltzerstrasse 3,

3012 Bern, Switzerland

e-mail: igor@geo.unibe.ch

I. M. Villa

Dipartimento di Scienze Geologiche e Geotecnologie,

Università di Milano Bicocca,

20126 Milan, Italy during the time in question. Specifically, during the Final Neolithic, we distinguished ten coherent clusters, confirmed by both the elemental compositions and lead isotope ratios. When compared to the Europe-wide database of copper ores, we observed significant changes in the provenance of the copper through time that reflect equally significant changes in social, cultural, and economic interactions.

Keywords Final Neolithic · Copper · Metal analysis . Lead isotope analysis $\cdot$ MC-ICP-MS

\section{Introduction}

Stemming from a doctoral research project at the University of Geneva, Switzerland (Cattin and Besse 2006; Cattin 2008, 2009), this paper focuses on prehistoric copper metallurgy in the Alps, specifically how sourcing provides insight into cultural patterns through space and time. The study presented here is part of a larger research project that aims to better understand third millennium $\mathrm{BC}$ cultural interaction in Europe, particularly within the Bell Beaker culture. Our approach is multifacetted, combining metal analysis (lead isotope and elemental composition), ceramic analysis and associated radiocarbon dates, territorial analysis, and anthropological analysis of nonmetric dental traits (Besse 2001, 2003; Desideri 2007; Piguet et al. 2007; Piguet and Besse 2009; Desideri et al. to be published).

Lead isotope analysis was first applied in archeology in the late 1960s by two independent teams (Grögler et al. 1966; Brill and Wampler 1965, 1967). Their approach used a lead isotope fingerprint from ore deposits that was compared to the fingerprint obtained from metal artifacts. Since its conception, lead isotope studies have focused on the provenance of the metal used to make the artifacts with 
initial questions focused on prehistoric economies. More recently, in a second phase of research, topics such as the social context of metal production (Gale et al. 2000), technology transfer (Stos-Gale 1989), modes of usage (Guénette-Beck 2005), and interactions (Cattin 2008) have been investigated.

During our doctoral research, metal analyses were conducted on 180 artifacts from various Final Neolithic (2900 BC to $2450 \mathrm{BC}$ ), Bell Beaker (2450 BC to 2150 $\mathrm{BC}$ ), and Early Bronze Age (2200 BC to $1550 \mathrm{BC}$ ) archeological sites in western Switzerland. In this paper, we present only a part of our results. Our goal is to demonstrate the high variability in copper composition and how the compositional patterns change across space and through time. We focus on the Final Neolithic, specifically the rich collection of metal artifacts from the Saint-Blaise/ Bains-des-Dames site (Neuchâtel, Switzerland). Having produced one of the largest collections of copper artifacts for this period, this stratified lake dwelling is integral to furthering our understanding of site-wide cultural practices. More broadly, we aim to better understand the geographic origin and subsequent distribution of copper (raw material or artifact) via social and economic exchange networks.

\section{The Final Neolithic in the Three Lakes Region of Switzerland}

The archeological context

In the Three Lakes Region of Switzerland, the Final Neolithic (2900 BC to 2450 BC) is divided into two cultural periods: the Lüscherz (2900-2700 BC) and the Auvernier-Cordé (2700-2450 BC). The Lüscherz period is characterized by flint importation from France, especially the Grand-Pressigny region, as well as awls and stone bead types similar to those found across southern France (Stöckli 1995). Whereas the Lüscherz period was oriented toward the Mediterranean world, the Auvernier-Cordé period begins in $2700 \mathrm{BC}$ when the Three Lakes Region is first influenced by the Corded Ware complex group, a group centered in central Germany, Poland, and the Czech Republic that spread throughout north and northeastern Europe. Artifactually, the Auvernier-Cordé period is characterized by beakers with cord impressions on the neck and stone battle-axes. The westernmost limit of this culture was western Switzerland, and the rapidity of its expansion across the Swiss Plateau has led some scholars to suggest it was a migration of small groups from the east (Giligny and Michel 1995; Stöckli 1995; Michel 2002).

The end of the Final Neolithic coincides with a documented hiatus in lacustrine environments that may be responsible for a shift in settlement patterns. This period, the Bell Beaker period (2450-2200 BC), is marked by new cultural elements, including decorated bell-shaped pottery, common ware, wrist guards, buttons with Vperforations, and a rich iconography of anthropomorphic stelae (Gallay 1995).

The site of Saint-Blaise/Bains des Dames

The site of Saint-Blaise/Bains des Dames is located on the northern shore of Lake Neuchâtel. Like most lake dwellings from the circum-alpine region, it suffered from nineteenth century surveying following the Jura Waters Correction Project that lowered the lake level. After a series of underwater explorations, a 3-year-long (1984-1986) rescue excavation took place due to the construction of highway A5.

The excavation revealed a succession of several superimposed settlements that span the Late Neolithic (Horgen, 3139-3124 BC) and the Final Neolithic (Late Lüscherz, 27862702 BC, and Auvernier-Cordé, 2702-2540 BC). In order to maintain consistency with previous research, we have based our chronocultural attributions on the ceramostratigraphic correlation of Michel (2002).

The copper data set

The site of Saint-Blaise/Bains des Dames (Neuchâtel, Switzerland) has yielded approximately 100 stratified metal objects (Girardbille 1990, unpublished report, Office et Musée d'Archéologie du Canton de Neuchâtel). In the surrounding area, a similar quantity of copper artifacts is only found at the Vinelz site on the shoreline of the Lac de Bienne in Bern, Switzerland (Strahm 1971). Clearly the abundance of metal objects from Saint-Blaise/Bains des Dames is particularly remarkable for the Final Neolithic in this region.

Our study is based on 89 copper artifacts recovered during the 1984-1986 excavations. The data set consists of 36 beads (biconical, cylindrical, rounded, tube, and helical), 21 awls (three are in handles), nine sheet fragments, seven dagger blades (this category takes into account a long thin sheet of copper), five rivets, five rods, two wires, two bracelets, one axe, and one long thin copper sheet.

Within our dataset, we have varying levels of certainty in the cultural affiliations of each object depending on whether or not an artifact was found within a common $640 \mathrm{~m}^{2}$ study area (48 inside, 39 outside, and two out of context). Within the common study area, there are two levels of certainty. If the associated ceramostratigraphic assemblage (Michel 2002) is homogeneous in a particular excavation unit, then the chronotypological attribution for those artifacts is strong. As a result, we are confident that five objects 
belong to the Early Auvernier-Cordé (2702-2673 BC), 16 to the Middle Auvernier-Cordé (2639-2560 BC), and two to the Late Auvernier-Cordé $(2560-2540$ BC). If the ceramostratigraphic assemblage is heterogeneous, however, the cultural affiliations are less reliable. Meaning that the 25 remaining artifacts from within the common area are attributed with less certainty to the Lüscherz $(n=2)$, the Early Auvernier-Cordé $(n=9)$, and the Middle AuvernierCordé $(n=14) .{ }^{1}$ The dates for the 39 objects from outside the common study area are less reliable because of poorer stratigraphic information. Therefore, the chronological attributions for these artifacts are based on the ceramic types.

The elemental compositions for 76 artifacts in our dataset were previously determined by Deffner (1993) using instrumental neutron activation analysis at the Max Planck-Institut für Kernphysik in Heidelberg, Germany. Two of the analyzed artifacts produced inconsistent silver and iron measurements, meaning they are in all likelihood modern (SB 12515 and SB 12536). We conducted lead isotope analysis on 53 of the artifacts at the Laboratory of Isotope Geology at the University of Bern. Two additional analyses were carried out, one on a pendant from the nineteenth century collections and the other on a rivet, making a total of 55 lead isotope analyses.

\section{Analytical methods}

Lead isotope analyses were performed using a $\mathrm{Nu}$ Instruments ${ }^{\mathrm{TM}}$ multicollector inductively coupled plasma mass spectrometer at the Laboratory of Isotope Geology at the University of Bern (Prof. I. M. Villa and Prof. J. Kramers). Of copper, 1-2-mg samples were obtained by drilling the objects with a 1-mm-diameter bit drill column. After removal of the altered surface, the core metal shavings are separated from the remaining corroded material under a binocular microscope. The samples are then dissolved in aqua regia and subjected to a procedure that collects the

\footnotetext{
${ }^{1}$ Inventory numbers for (1) homogeneous contexts-Early AuvernierCordé: SB 12578, SB 12587, SB 12533, SB 12535, SB 12548; Middle Auvernier-Cordé: SB 12551, SB 12572, SB 12573, SB 12593, SB 12594, SB 12538, SB 12529, SB 12570, SB 12591, SB 12592, SB 12567, SB 12568, SB 12569, SB 12597, SB 12598, SB 12599; and Late Auvernier-Cordé: SB 12555, SB 15009 and (2) heterogeneous contexts-Lüscherz: SB 12531, SB 12546; Early Auvernier-Cordé: SB 12553, SB 766, SB 12537, SB 12540, SB 12542, SB 12543, SB 12544, SB 12595, SB 12552; and Middle Auvernier-Cordé: SB 12554, SB 12571, SB 12539, SB 12530, SB 12547, SB 15003, SB 12527, SB 12528, SB 15005, SB 12596, SB 12511, SB 12512, SB 12514, SB 12516.
}

lead on cation exchange resins, as detailed in Cattin (2008). Next, the sample is introduced into a liquid solution containing thallium to correct for the mass bias of the instrument. Several measurements of the standard NIST SRM 981, performed to estimate the precision of the spectrometry, yielded values that compare favorably with those reported in the literature (Galer and Abouchami 1998). Thus, we present here our measured values without any further bias correction (Table 1), with the exception of the measurements conducted on September 24, 2007. Due to analytical problems, a correction was applied to samples SB 12508, SB 12510, SB 12539, SB 12592, SB 12531, SB 12596, SB 12578, SB 12538, and SB 12574, thanks to three measurements of the standard and replicating measurements for five objects. The mean standard deviation for the NIST SRM 981 measurements per day gives the following errors (2 sigma): 0.019 for the ${ }^{208} \mathrm{~Pb} /{ }^{204} \mathrm{~Pb}$ ratio, 0.007 for the ${ }^{207} \mathrm{~Pb} /{ }^{204} \mathrm{~Pb}$ ratio, 0.007 for the ${ }^{206} \mathrm{~Pb} /{ }^{204} \mathrm{~Pb}$ ratio, 0.00054 for the ${ }^{208} \mathrm{~Pb} /{ }^{206} \mathrm{~Pb}$ ratio, and 0.000018 for the ${ }^{207} \mathrm{~Pb} /{ }^{206} \mathrm{~Pb}$ ratio.

\section{Data and results}

Trace element pattern

\section{Classification}

The results of the elemental composition analyses (Deffner 1993) have been sorted using the classification of the Stuttgart research project (Junghans et al. 1960, 19681974; Table 2). This system creates groups and is widely used for archeological analysis. Using cluster analysis, Pernicka (1990) has identified five main copper types: fahlore type copper with and without nickel, pure copper, antimony copper, and arsenic copper.

At Saint-Blaise/Bains des Dames, the copper types are, by order of importance, pure copper $(n=33)$, often containing a high nickel content (group FC of Junghans et al. 1960, 1968-1974), fahlore type copper $(n=27)$, antimony copper $(n=19)$, and arsenic copper $(n=2)$. Among 81 analyses, 43 are placed in 18 copper groups, as detailed in Table 2. The remaining 38 cannot be classified because they lack a bismuth measurement.

\section{Correlation between chemical elements as a tool to trace a similar copper source}

Three correlation diagrams (see Cattin 2008 for further details) have been produced to demonstrate the artifact clusters with similar $\mathrm{Ag} / \mathrm{Au}, \mathrm{Sb} / \mathrm{As}$, and $\mathrm{Co} / \mathrm{Ni}$ ratios. Following other researchers (Pernicka 1990), we assume 
Table 1 Lead isotope ratios ( \pm 2 sigma) of copper objects from the Saint-Blaise/Bains des Dames site (Neuchâtel, Switzerland)

\begin{tabular}{|c|c|c|c|c|c|c|}
\hline Inventory no. & Type & ${ }^{208} \mathrm{~Pb} /{ }^{204} \mathrm{~Pb}$ & ${ }^{207} \mathrm{~Pb} /{ }^{204} \mathrm{~Pb}$ & ${ }^{206} \mathrm{~Pb} /{ }^{204} \mathrm{~Pb}$ & ${ }^{208} \mathrm{~Pb} /{ }^{206} \mathrm{~Pb}$ & ${ }^{207} \mathrm{~Pb} /{ }^{206} \mathrm{~Pb}$ \\
\hline SB 38 & Pendant & $38.547 \pm 0.007$ & $15.686 \pm 0.002$ & $18.465 \pm 0.004$ & $2.08765 \pm 0.00015$ & $0.84948 \pm 0.00003$ \\
\hline SB 12505 & Awl & $38.331 \pm 0.198$ & $15.612 \pm 0.095$ & $18.358 \pm 0.092$ & $2.08761 \pm 0.00069$ & $0.85192 \pm 0.00034$ \\
\hline SB 12506 & Dagger blade & $38.422 \pm 0.020$ & $15.678 \pm 0.011$ & $18.369 \pm 0.010$ & $2.09189 \pm 0.00014$ & $0.85389 \pm 0.00005$ \\
\hline SB 12507 & Sheet & $38.911 \pm 0.006$ & $15.698 \pm 0.003$ & $18.822 \pm 0.002$ & $2.06728 \pm 0.00013$ & $0.83401 \pm 0.00005$ \\
\hline SB 12508 & Sheet & $38.752 \pm 0.004$ & $15.685 \pm 0.001$ & $18.636 \pm 0.001$ & $2.07940 \pm 0.00008$ & $0.84162 \pm 0.00002$ \\
\hline SB 12510 & Sheet & $38.525 \pm 0.008$ & $15.682 \pm 0.003$ & $18.443 \pm 0.004$ & $2.08885 \pm 0.00013$ & $0.85030 \pm 0.00004$ \\
\hline SB 12511 & Bead & $38.794 \pm 0.028$ & $15.720 \pm 0.012$ & $18.747 \pm 0.014$ & $2.06944 \pm 0.00025$ & $0.83853 \pm 0.00008$ \\
\hline SB 12512 & Bead & $38.789 \pm 0.189$ & $15.694 \pm 0.079$ & $19.129 \pm 0.095$ & $2.02777 \pm 0.00039$ & $0.82042 \pm 0.00019$ \\
\hline SB 12514 & Bead & $38.365 \pm 0.143$ & $15.646 \pm 0.043$ & $18.362 \pm 0.049$ & $2.08640 \pm 0.00053$ & $0.85199 \pm 0.00017$ \\
\hline SB 12515 & Bracelet & $38.463 \pm 0.051$ & $15.672 \pm 0.021$ & $18.385 \pm 0.025$ & $2.09189 \pm 0.00021$ & $0.85241 \pm 0.00007$ \\
\hline SB 12517 & Awl & $38.937 \pm 0.009$ & $15.708 \pm 0.003$ & $18.836 \pm 0.002$ & $2.06715 \pm 0.00014$ & $0.83394 \pm 0.00004$ \\
\hline SB 12518 & Dagger blade & $37.877 \pm 0.006$ & $15.612 \pm 0.001$ & $18.037 \pm 0.003$ & $2.10013 \pm 0.00017$ & $0.86555 \pm 0.00011$ \\
\hline SB 12519 & Bead & $38.589 \pm 0.007$ & $15.699 \pm 0.003$ & $18.472 \pm 0.003$ & $2.08901 \pm 0.00016$ & $0.84982 \pm 0.00004$ \\
\hline SB 12520 & Bead & $38.523 \pm 0.008$ & $15.678 \pm 0.003$ & $18.448 \pm 0.003$ & $2.08829 \pm 0.00015$ & $0.84984 \pm 0.00005$ \\
\hline SB 12521 & Bead & $38.392 \pm 0.078$ & $15.713 \pm 0.031$ & $18.318 \pm 0.036$ & $2.09570 \pm 0.00026$ & $0.85778 \pm 0.00013$ \\
\hline SB 12522 & Triangular blade (dagger?) & $38.095 \pm 0.068$ & $15.534 \pm 0.029$ & $18.259 \pm 0.034$ & $2.08625 \pm 0.00037$ & $0.85085 \pm 0.00026$ \\
\hline SB 12524 & Dagger blade & $38.528 \pm 0.027$ & $15.716 \pm 0.010$ & $18.560 \pm 0.012$ & $2.07529 \pm 0.00027$ & $0.84658 \pm 0.00011$ \\
\hline SB 12528 & Bead & $38.146 \pm 0.004$ & $15.651 \pm 0.002$ & $17.913 \pm 0.003$ & $2.12965 \pm 0.00015$ & $0.87376 \pm 0.00003$ \\
\hline SB 12529 & Bead & $38.431 \pm 0.013$ & $15.686 \pm 0.003$ & $18.422 \pm 0.003$ & $2.08639 \pm 0.00026$ & $0.85155 \pm 0.00005$ \\
\hline SB 12531 & Narrow blade & $37.883 \pm 0.024$ & $15.469 \pm 0.011$ & $18.217 \pm 0.011$ & $2.07957 \pm 0.00014$ & $0.84917 \pm 0.00013$ \\
\hline SB 12533 & Awl & $38.452 \pm 0.014$ & $15.698 \pm 0.007$ & $18.495 \pm 0.006$ & $2.07922 \pm 0.00013$ & $0.84880 \pm 0.00004$ \\
\hline SB 12535 & Awl & $37.915 \pm 0.025$ & $15.582 \pm 0.010$ & $18.063 \pm 0.012$ & $2.09908 \pm 0.00011$ & $0.86269 \pm 0.00005$ \\
\hline SB 12537 & Bead & $38.250 \pm 0.006$ & $15.613 \pm 0.002$ & $18.311 \pm 0.003$ & $2.08890 \pm 0.00014$ & $0.85267 \pm 0.00004$ \\
\hline SB 12538 & Bead & $38.604 \pm 0.010$ & $15.627 \pm 0.004$ & $18.670 \pm 0.004$ & $2.06770 \pm 0.00016$ & $0.83702 \pm 0.00007$ \\
\hline SB 12539 & Awl & $38.574 \pm 0.009$ & $15.682 \pm 0.004$ & $18.413 \pm 0.004$ & $2.09492 \pm 0.00008$ & $0.85170 \pm 0.00005$ \\
\hline SB 12546 & Bead & $38.932 \pm 0.013$ & $15.702 \pm 0.004$ & $18.812 \pm 0.005$ & $2.06919 \pm 0.00016$ & $0.83467 \pm 0.00004$ \\
\hline SB 12548 & Sheet & $38.206 \pm 0.013$ & $15.600 \pm 0.005$ & $18.325 \pm 0.006$ & $2.08493 \pm 0.00016$ & $0.85125 \pm 0.00005$ \\
\hline SB 12549 & Bead & $38.133 \pm 0.008$ & $15.660 \pm 0.003$ & $17.881 \pm 0.003$ & $2.13263 \pm 0.00016$ & $0.87576 \pm 0.00006$ \\
\hline SB 12551 & Awl & $38.591 \pm 0.019$ & $15.692 \pm 0.009$ & $18.492 \pm 0.003$ & $2.08672 \pm 0.00051$ & $0.84871 \pm 0.00036$ \\
\hline SB 12552 & Awl & $38.574 \pm 0.007$ & $15.696 \pm 0.003$ & $18.471 \pm 0.004$ & $2.08858 \pm 0.00012$ & $0.84982 \pm 0.00003$ \\
\hline SB 12553 & Sheet & $38.083 \pm 0.040$ & $15.612 \pm 0.018$ & $18.187 \pm 0.020$ & $2.09362 \pm 0.00023$ & $0.85849 \pm 0.00009$ \\
\hline SB 12556 & Bead & $37.932 \pm 0.005$ & $15.597 \pm 0.002$ & $18.104 \pm 0.002$ & $2.09515 \pm 0.00009$ & $0.86152 \pm 0.00003$ \\
\hline SB 12557 & Bead & $38.210 \pm 0.011$ & $15.601 \pm 0.005$ & $18.291 \pm 0.006$ & $2.08894 \pm 0.00013$ & $0.85287 \pm 0.00004$ \\
\hline SB 12558 & Dagger blade & $37.759 \pm 0.029$ & $15.612 \pm 0.009$ & $17.829 \pm 0.017$ & $2.11696 \pm 0.00082$ & $0.87616 \pm 0.00009$ \\
\hline SB 12565 & Bead & $38.007 \pm 0.009$ & $15.576 \pm 0.004$ & $18.237 \pm 0.003$ & $2.08381 \pm 0.00013$ & $0.85398 \pm 0.00005$ \\
\hline SB 12567 & Bead & $38.178 \pm 0.005$ & $15.657 \pm 0.002$ & $17.926 \pm 0.002$ & $2.12974 \pm 0.00018$ & $0.87340 \pm 0.00008$ \\
\hline SB 12568 & Bead & $38.191 \pm 0.004$ & $15.664 \pm 0.001$ & $17.920 \pm 0.001$ & $2.13114 \pm 0.00009$ & $0.87409 \pm 0.00002$ \\
\hline SB 12570 & Sheet & $38.161 \pm 0.005$ & $15.657 \pm 0.002$ & $17.910 \pm 0.002$ & $2.13068 \pm 0.00010$ & $0.87419 \pm 0.00003$ \\
\hline SB 12573 & Bead & $37.506 \pm 0.040$ & $15.565 \pm 0.015$ & $17.638 \pm 0.016$ & $2.12653 \pm 0.00073$ & $0.88259 \pm 0.00017$ \\
\hline SB 12574 & Awl & $38.846 \pm 0.009$ & $15.695 \pm 0.002$ & $18.777 \pm 0.003$ & $2.06886 \pm 0.00012$ & $0.83587 \pm 0.00005$ \\
\hline SB 12576 & Bead & $38.588 \pm 0.111$ & $15.688 \pm 0.045$ & $18.566 \pm 0.050$ & $2.07813 \pm 0.00046$ & $0.84498 \pm 0.00032$ \\
\hline SB 12577 & Sheet & $38.544 \pm 0.006$ & $15.711 \pm 0.002$ & $18.399 \pm 0.002$ & $2.09494 \pm 0.00009$ & $0.85389 \pm 0.00003$ \\
\hline SB 12578 & Bead & $38.253 \pm 0.022$ & $15.590 \pm 0.009$ & $18.388 \pm 0.010$ & $2.03031 \pm 0.00016$ & $0.84782 \pm 0.00006$ \\
\hline SB 12581 & Dagger blade & $38.432 \pm 0.006$ & $15.671 \pm 0.002$ & $18.460 \pm 0.002$ & $2.08189 \pm 0.00009$ & $0.84887 \pm 0.00003$ \\
\hline SB 12592 & Awl & $38.580 \pm 0.013$ & $15.717 \pm 0.004$ & $18.455 \pm 0.002$ & $2.09047 \pm 0.00036$ & $0.85164 \pm 0.00003$ \\
\hline SB 12594 & Rod & $38.580 \pm 0.006$ & $15.692 \pm 0.002$ & $18.492 \pm 0.003$ & $2.08652 \pm 0.00013$ & $0.84871 \pm 0.00003$ \\
\hline SB 12596 & Bead & $38.249 \pm 0.008$ & $15.666 \pm 0.002$ & $17.998 \pm 0.002$ & $2.12521 \pm 0.00017$ & $0.87045 \pm 0.00004$ \\
\hline SB 12597 & Bead & $38.513 \pm 0.005$ & $15.676 \pm 0.002$ & $18.449 \pm 0.005$ & $2.08777 \pm 0.00011$ & $0.84981 \pm 0.00008$ \\
\hline SB 12598 & Bead & $38.613 \pm 0.003$ & $15.698 \pm 0.001$ & $18.497 \pm 0.001$ & $2.08753 \pm 0.00011$ & $0.84868 \pm 0.00003$ \\
\hline
\end{tabular}


Table 1 (continued)

\begin{tabular}{lllllll}
\hline Inventory no. & Type & ${ }^{208} \mathrm{~Pb} /{ }^{204} \mathrm{~Pb}$ & ${ }^{207} \mathrm{~Pb} /{ }^{204} \mathrm{~Pb}$ & ${ }^{206} \mathrm{~Pb} /{ }^{204} \mathrm{~Pb}$ & ${ }^{208} \mathrm{~Pb} /{ }^{206} \mathrm{~Pb}$ & ${ }^{207} \mathrm{~Pb} /{ }^{206} \mathrm{~Pb}$ \\
\hline SB 12599 & Bead & $38.556 \pm 0.005$ & $15.689 \pm 0.002$ & $18.457 \pm 0.002$ & $2.08897 \pm 0.00009$ & $0.85003 \pm 0.00003$ \\
SB 12601 & Awl & $38.496 \pm 0.015$ & $15.698 \pm 0.006$ & $18.364 \pm 0.006$ & $2.09606 \pm 0.00022$ & $0.85481 \pm 0.00003$ \\
SB 15003 & Rod & $38.292 \pm 0.009$ & $15.630 \pm 0.004$ & $18.475 \pm 0.003$ & $2.07269 \pm 0.00016$ & $0.84603 \pm 0.00005$ \\
SB 15006 & Sheet & $38.189 \pm 0.026$ & $15.647 \pm 0.010$ & $18.364 \pm 0.012$ & $2.07962 \pm 0.00020$ & $0.85205 \pm 0.00007$ \\
SB 15008 & Axe blade fragment & $38.621 \pm 0.005$ & $15.693 \pm 0.002$ & $18.434 \pm 0.003$ & $2.09515 \pm 0.00013$ & $0.85130 \pm 0.00004$ \\
SB 12518 & Rivet (central) & $37.557 \pm 0.007$ & $15.582 \pm 0.003$ & $17.741 \pm 0.002$ & $2.11702 \pm 0.00013$ & $0.87834 \pm 0.00004$ \\
\hline
\end{tabular}

Table 2 Elemental composition sorted according to the classification system of Junghans et al. (1960, 1968-1974) and the copper types defined by Pernicka (1990)

\begin{tabular}{|c|c|c|}
\hline Inventory no. & Copper type (Pernicka 1990) & Copper group (Junghans et al. 1968-1974) \\
\hline SB 38 & Antimony copper & E10 \\
\hline SB 38 & Fahlore type copper with $\mathrm{Ni}$ & $\mathrm{E} 11 \mathrm{~A}$ \\
\hline SB 12505 & Pure copper & $\mathrm{FC}$ \\
\hline SB 12506 & Fahlore type copper & I \\
\hline SB 12507 & Arsenic copper & FA \\
\hline SB 12508 & Fahlore type copper with $\mathrm{Ni}$ & G \\
\hline SB 12510 & Fahlore type copper without $\mathrm{Ni}$ & C6B \\
\hline SB 12511 & Fahlore type copper & I \\
\hline SB 12512 & Fahlore type copper & I \\
\hline SB 12516 & Fahlore type copper with $\mathrm{Ni}$ & $\mathrm{A}$ \\
\hline SB 12517 & Pure copper & $\mathrm{FC}$ \\
\hline SB 12518 & Fahlore type copper & I \\
\hline SB 12518 & Fahlore type copper & I \\
\hline SB 12518 & Fahlore type copper & I \\
\hline SB 12519 & Antimony copper & FD \\
\hline SB 12520 & Fahlore type copper with $\mathrm{Ni}$ & FG \\
\hline SB 12521 & Fahlore type copper with $\mathrm{Ni}$ & $\mathrm{B} 2$ \\
\hline SB 12522 & Pure copper & III \\
\hline SB 12524 & Fahlore type copper & I \\
\hline SB 12525 & Pure copper & III \\
\hline SB 12527 & Fahlore type copper & I \\
\hline SB 12528 & Antimony copper & E10 \\
\hline SB 12529 & Antimony copper & IV a \\
\hline SB 12530 & Fahlore type copper with Ni & FG \\
\hline SB 12531 & Pure copper & $\mathrm{FC}$ \\
\hline SB 12533 & Fahlore type copper & I \\
\hline SB 12535 & Pure copper & $\mathrm{FC}$ \\
\hline SB 12537 & Pure copper & III \\
\hline SB 12538 & Pure copper & $\mathrm{FC}$ \\
\hline SB 12539 & Fahlore type copper with Ni & A2 \\
\hline SB 12542 & Pure copper & $\mathrm{FC}$ \\
\hline SB 12543 & Antimony copper & IV a \\
\hline SB 12544 & Pure copper & III \\
\hline SB 12546 & Arsenic copper & FA \\
\hline SB 12547 & Pure copper & III \\
\hline SB 12548 & Pure copper & III \\
\hline
\end{tabular}


Table 2 (continued)

Inventory no.

Copper type (Pernicka 1990)

Copper group (Junghans et al. 1968-1974)

SB 12549

SB 12550

SB 12551

SB 12552

SB 12553

SB 12555

SB 12556

SB 12557

SB 12558

SB 12558

SB 12558

SB 12559

SB 12560

SB 12561

SB 12561

SB 12564

SB 12565

SB 12567

SB 12568

SB 12569

SB 12570

SB 12571

SB 12572

SB 12573

SB 12574

SB 12576

SB 12577

SB 12578

SB 12579

SB 12580

SB 12581

SB 12582

SB 12590

SB 12591

SB 12592

SB 12594

SB 12595

SB 12596

SB 12597

SB 12598

SB 12599

SB 15003

SB 15005

SB 15006

SB 15008
Antimony copper

Antimony copper

Fahlore type copper

Antimony copper

Pure copper

Pure copper

Pure copper

Pure copper

Fahlore type copper

Pure copper

Pure copper

Pure copper

Antimony copper

Pure copper

Pure copper

Pure copper

Pure copper

Antimony copper

Antimony copper

Antimony copper

Antimony copper

Pure copper

Pure copper

Pure copper

Pure copper

Pure copper

Antimony copper

Pure copper

Fahlore type copper without Ni

Antimony copper

Fahlore type copper with Ni

Fahlore type copper

Fahlore type copper

Pure copper

Fahlore type copper without $\mathrm{Ni}$

Fahlore type copper with $\mathrm{Ni}$

Pure copper

Antimony copper

Fahlore type copper with $\mathrm{Ni}$

Antimony copper

Antimony copper

Pure copper

Fahlore type copper with Ni

Pure copper

Antimony copper
E10

E10

I

FD

III

III

FC

III

I

FC

FC

III

IV a

III

III

III

III

C4

FD

IV a

IV a

III

E00

FC

E00FC

III

IV a

FC

II a

C4

B2

I

I

C1A

C2D

B2

III

C1B

A1

FD

C4

E00

B2

III

FD

From a total of 81 analyses, 43 are placed in 18 copper groups. The lack of a bismuth measurement makes the remaining 38 unclassifiable; for these, we propose a less detailed classification system (groups I, II a, III, IV a) 
that some selected elements provide valuable information when attributing two or more artifacts to the same source. As a result of this "a priori" assumption, only one possible correlation between eight analyses can be seen on the $\mathrm{Sb} /$ As diagram that is confirmed by the lead isotope ratios for only three of the artifacts (see below, pole Neo: d).

\section{Alloying}

An alloy is the intentional addition of another component to metal in order to alter its properties. For copper, the most frequent additions in prehistoric Europe were arsenic, tin, and lead (Ottaway 1994; Rychner and Kläntschi 1995). A 1-2\% arsenic content is consistent with the smelting of fahlores, as is a high content of antimony and/or silver. The sample SB 38 does show a 1.9\% tin content; however (Ottaway 1982; Krause 2003), tin alloying is unlikely. This particularly high tin content is not surprising given that similar tin contents are found in association with the Corded Ware culture complex in Bohemia, Moravia, and central Germany, and some of the artifacts found at Saint-Blaise/Bains des Dames (Neuchâtel, Switzerland) show comparable values of tin (Krause 2003). Such tin content is too low to have an impact on the metal properties. As of yet, its purpose is not satisfactorily explained. As reported in the Erzgebirge,
Germany, it may be the result of mining copper ores containing tin (Niederschlag et al. 2003).

Lead isotope ratios and the determination of groups related to a similar source

Measurements of all 55 isotopic analyses are summarized in Table 1. Their graphic representations in Figs. 1 and 2 show a wide range of values, demonstrating the complexity of the copper supply during the Final Neolithic. On the ${ }^{207} \mathrm{~Pb} /{ }^{204} \mathrm{~Pb}$ versus ${ }^{206} \mathrm{~Pb} /{ }^{204} \mathrm{~Pb}$ diagram (Fig. 2), the archeological data are compared with the evolution lines reported for the five lead reservoirs-namely old upper crust, young upper crust, upper mantle, young lower crust, and old lower crust - defined by Kramers and Tolstikhin (1997). Some values suggest a mantelic influence but most of them plot between the young upper crust and the old upper crust lines. When interpreted with caution, the ${ }^{207} \mathrm{~Pb} /{ }^{204} \mathrm{~Pb}$ and ${ }^{206} \mathrm{~Pb} /{ }^{204} \mathrm{~Pb}$ ratios reflect the geochronology of mineralization because the amount of ${ }^{204} \mathrm{~Pb}$ is constant from the formation of the Earth, whereas ${ }^{207} \mathrm{~Pb}$ and ${ }^{206} \mathrm{~Pb}$, the decay products of ${ }^{235} \mathrm{U}$ and ${ }^{238} \mathrm{U}$, respectively, increase with time (Faure 1986).

Using the elemental compositions and the lead isotope ratios, our goal is to clarify the source relationships between the artifacts in our dataset. We do this by comparing both
Fig. 1 Comparison of the ${ }^{208} \mathrm{~Pb} /{ }^{206} \mathrm{~Pb}$ and ${ }^{207} \mathrm{~Pb} /{ }^{206} \mathrm{~Pb}$ ratios. The symbols represent the copper type (Pernicka 1990) and, when available, the copper groups as well (Junghans et al. 1968-1974)

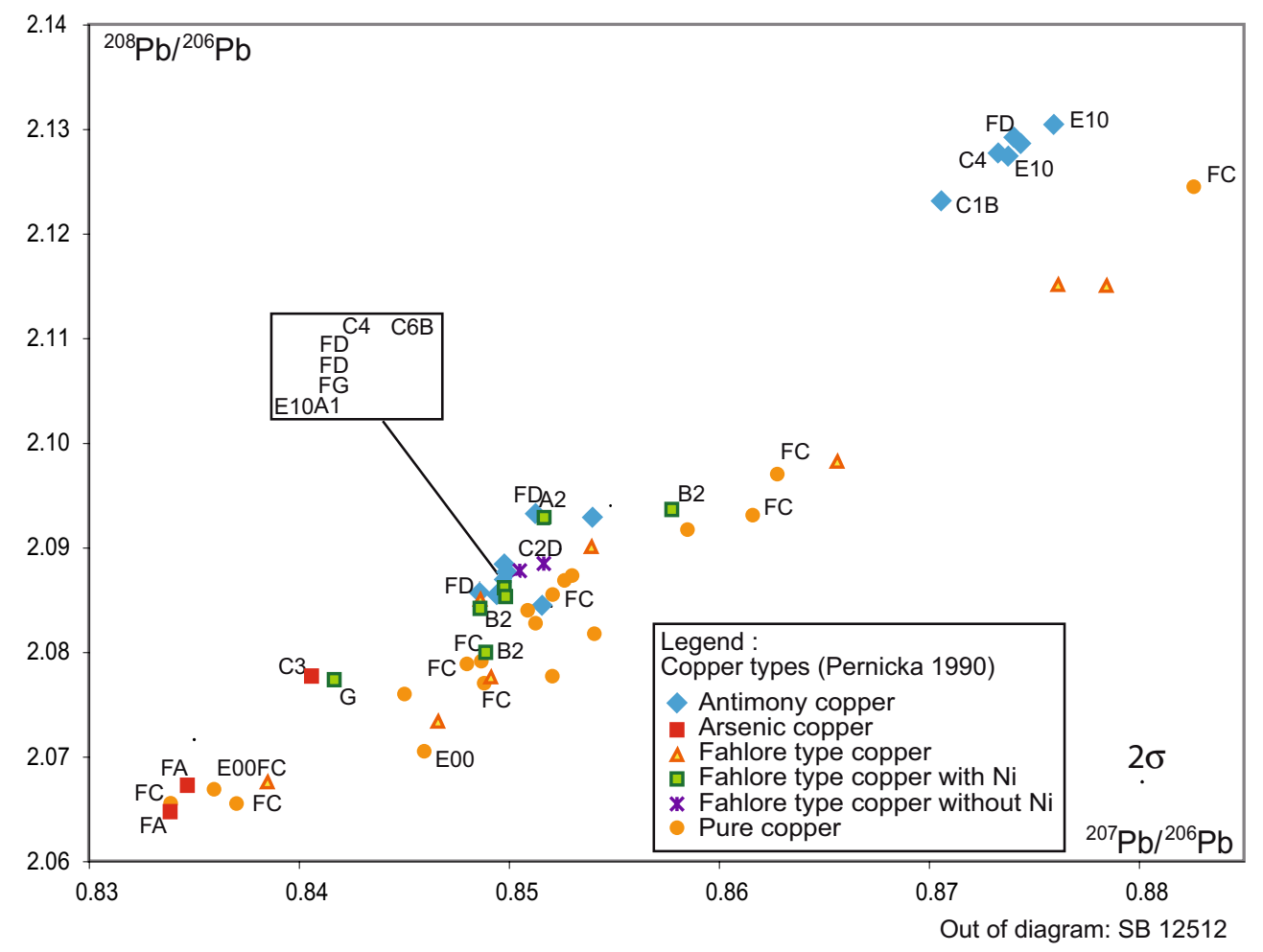


Fig. 2 Comparison of the ${ }^{207} \mathrm{~Pb} /{ }^{204} \mathrm{~Pb}$ and ${ }^{206} \mathrm{~Pb} /{ }^{204} \mathrm{~Pb}$ ratios. The symbols represent the copper types (Pernicka 1990) and, when available, the copper groups as well (Junghans et al. 1968-1974)

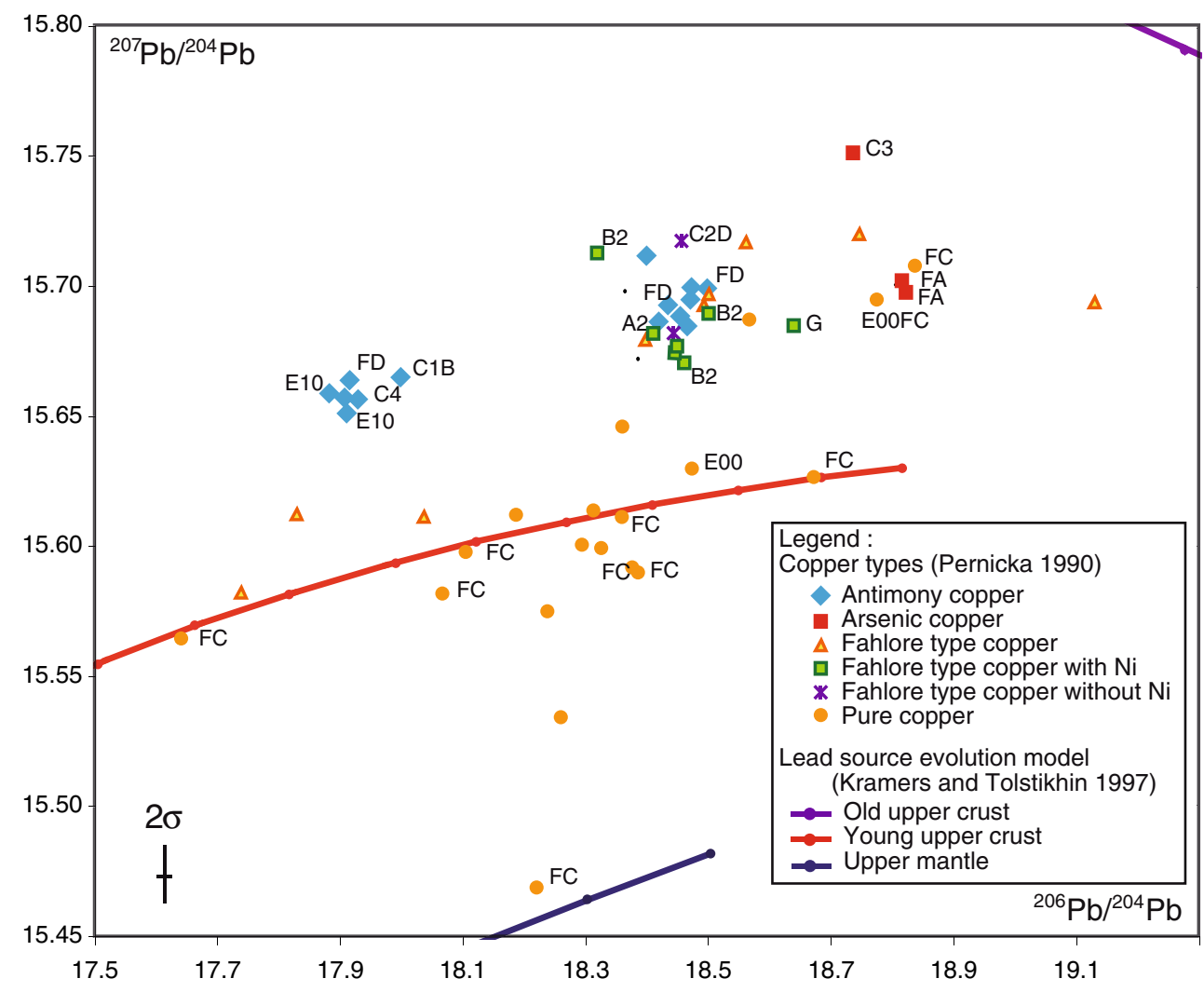

lead isotope ratios and elemental compositions from the more general to the more detailed descriptions, i.e., the copper groups, the copper types, then the correlations between elements $\mathrm{Sb} / \mathrm{As}, \mathrm{Co} / \mathrm{Ni}$, and $\mathrm{Au} / \mathrm{Ag}$. While the copper groups and types furnish indications of the mineral types present in mined copper ores, the elemental correlations may indicate a similar source. Thus, using both analytical techniques, we seek to distinguish coherent clusters to determine the provenance of the copper samples. At this state of research, these groups are referred to as "poles", defined as an isotopic field carrying the signature of a copper source or a group of predominant copper sources, and are distinguished, at the scale of archeological object, by a coherent set of analyses as much by the chemical element composition as by the lead isotope composition, or by an independent analysis that cannot result from the mixture of sources attested by other contemporaneous archeological objects.

Figures 1 and 2 compare the lead isotope ratios to copper types. Specifically the ${ }^{207} \mathrm{~Pb} /{ }^{204} \mathrm{~Pb}$ versus ${ }^{206} \mathrm{~Pb} /{ }^{204} \mathrm{~Pb}$ diagram (Fig. 2), it is noteworthy that the lead isotope compositions of pure copper correspond mostly to mantle derived sources, whereas other copper types appear between the young upper crust and the old upper crust. A correlation thus exists between lead isotope ratios and the elemental compositions; the distinct provenances of the copper supply are related to different kinds of copper ores. Superimposed on the lead isotope ratios, the copper groups prove to be irrelevant, except for the group FC, a copper with high nickel content and particular to the Final Neolithic of western Switzerland (Strahm 1994). The lead isotope ratios showing a mantelic influence belong to the group FC (when the group could be determined), and this group probably comes from several mines.

An examination on scatter diagrams of the elemental correlations conducted on the 54 Final Neolithic objectsincluding two awls from Concise/sous-Colachoz (Vaud, Switzerland) and one axe found in Vétroz (Valais, Switzerland)_-identified ten poles (Fig. 3; Table 3) comprising 22 artifacts from Saint-Blaise/Bains des Dames site. The remaining objects are difficult, if not impossible to include because isolated analyses represent a multitude of mines or a mixture of one or several sources, following diverse technological processes. Faced with the unknown elements, we were forced to exclude them from the sourcing study. 
Fig. 3 Copper artifacts from Saint-Blaise/Bains des Dames (Neuchâtel, Switzerland) arranged into the ten poles identified for the Final Neolithic. Note the different scales (Drawings by V. Loeliger)

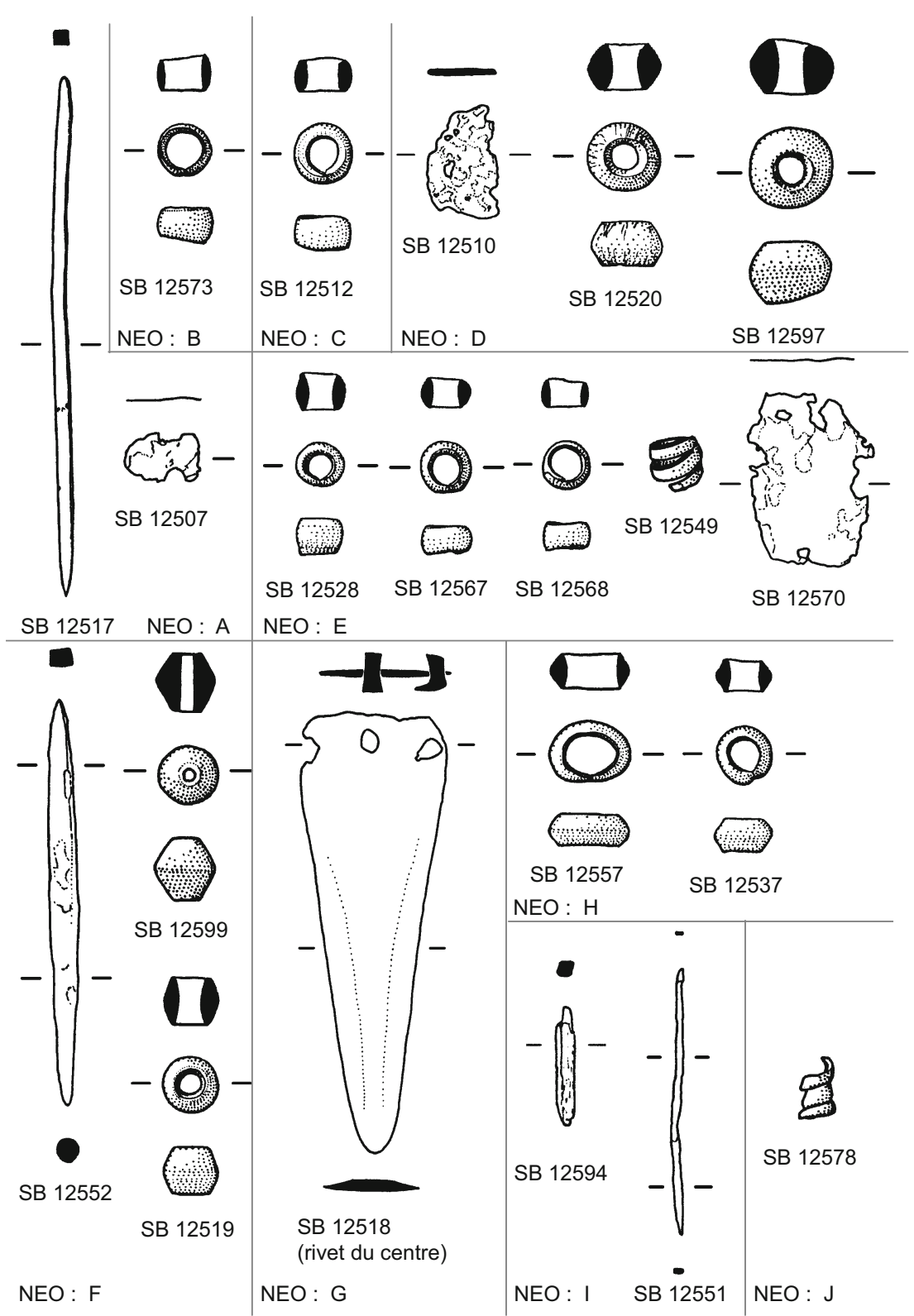

Changes in copper supply during the Final Neolithic

A number of objects in the dataset have sound stratigraphic context, allowing us to classify them into an early (LüscherzEarly Auvernier-Cordé) or late (Middle Auvernier-Cordé and Late Auvernier-Cordé) phase of the Final Neolithic. The copper types and lead isotope ratios both clearly indicate a change from the early to the late phase that may be related to a change in the copper supply at this time. The early phase $(n=8)$ is characterized by pure copper $(n=6)$, which is frequently associated with a high content of nickel. The late phase, in contrast, is dominated by copper with a high content of antimony $(n=8)$, followed by pure copper $(n=5)$ and fahlore type copper $(n=4)$. The antimony copper and the fahlore type copper are consistent with tennantite and tetrahedrite smelting. In terms of lead isotope ratios, the artifacts are distinguished most often by low ${ }^{208} \mathrm{~Pb} /{ }^{206} \mathrm{~Pb}$ ratios and the presence of mantelic compositions during the early phase $(n=8)$ which are absent in the late phase $(n=14)$. 
Table 3 Proposed sources for the copper ores characterized by each of the ten poles identified for the Final Neolithic artifacts

\begin{tabular}{|c|c|c|c|c|}
\hline Pole & Copper type & Quantity & Inventory no. & Kind of source ore \\
\hline \multicolumn{5}{|c|}{ Late phase } \\
\hline Neo: $b$ & $\begin{array}{l}\text { Pure copper with } \\
\text { nickel }\end{array}$ & 1 & Bead SB 12573 & Association with mafic rocks \\
\hline Neo: c & $\begin{array}{l}\text { Fahlore type copper } \\
\text { with } \mathrm{Ni} \text { and As }\end{array}$ & 1 & Bead SB 12512 & $\begin{array}{l}\text { Ore of the tennantite-tetrahedrite series, mineral } \\
\text { association with } \mathrm{Ni}+\mathrm{As}\end{array}$ \\
\hline Neo: d & $\begin{array}{l}\text { Fahlore type copper } \\
\text { with or without } \mathrm{Ni}\end{array}$ & 3 & $\begin{array}{l}\text { Sheet SB 12510, bead SB } 12520 \text {, bead SB } \\
12597\end{array}$ & Ore of the tennantite-tetrahedrite series \\
\hline Neo: e & Antimony copper & 5 & $\begin{array}{c}\text { Bead SB } 12528 \text {, bead SB } 12549 \text {, bead SB } \\
12567 \text {, bead SB } 12568 \text {, sheet SB } 12570\end{array}$ & Ore of the tennantite-tetrahedrite series \\
\hline Neo: $f$ & Antimony copper & 3 & $\begin{array}{l}\text { Bead SB } 12519 \text {, awl SB } 12552 \text {, bead SB } \\
12599 \text { (+ pendent SB } 38 ?)\end{array}$ & $\begin{array}{l}\text { Ore of the tennantite-tetrahedrite series with high } \\
\text { content of antimony (e.g. tetrahedrite, bournonite) }\end{array}$ \\
\hline Neo: $g$ & Fahlore type copper & 1 & Rivet SB 12518 (central) & Ore of the tennantite-tetrahedrite series \\
\hline Neo: i & Fahlore type copper & 2 & Awl SB 12551, rod SB 12594 & Ore of the tennantite-tetrahedrite series \\
\hline \multicolumn{5}{|c|}{ Early phase } \\
\hline Neo: $h$ & $\begin{array}{l}\text { Pure copper with } \\
\text { nickel }\end{array}$ & 2 & Bead SB 12537, bead SB 12557 & $\begin{array}{l}\text { Mineralisation with a mantlic source for the lead?; } \\
\text { association with mafic rocks }\end{array}$ \\
\hline Neo: $j$ & $\begin{array}{l}\text { Pure copper with } \\
\text { nickel }\end{array}$ & $2^{\mathrm{a}}$ & Bead SB 12578 & $\begin{array}{l}\text { Mineralisation with a mantlic source for the lead; } \\
\text { association with mafic rocks }\end{array}$ \\
\hline \multicolumn{5}{|c|}{ Undefined phase } \\
\hline Neo: a & Arsenic copper & 2 & Sheet SB 12507, awl SB 12517 & Copper ore on mineral association with $\mathrm{As}, \mathrm{Ni}, \mathrm{Ag}$ \\
\hline
\end{tabular}

${ }^{\mathrm{a}}$ Awl COC ZH215.25 from the Concise/sous-Colachoz site (Vaud, Switzerland) is included in pole Neo: $\mathrm{j}$ (Cattin 2008)

Fig. 4 Comparison of the ${ }^{208} \mathrm{~Pb} /{ }^{206} \mathrm{~Pb}$ and ${ }^{207} \mathrm{~Pb} /{ }^{206} \mathrm{~Pb}$ ratios. This diagram compares the lead isotope compositions for the Final Neolithic artifacts to the compositions of the possible ore bodies in Europe. For all values taken from the literature, we chose a $0.1 \%$ confidence interval; our own measurements have smaller errors. Note that pole NEO: $C$ overlaps with the Falkenstein-Eiblschrofen region (Schwaz-Brixlegg, Austria), the Tsampétroz mine in the Val d'Anniviers (Valais, Switzerland), Cork (Ireland), and Cornwall (England). Pole NEO: E overlaps with several ore bodies in Austria, the Kieserbezirk Villgraten area (Thurntaler, Tyrol), the Walchen/Öblarn mine (Ennstal, Eisenerz, Styria and Upper Austria), and the

Schwaz-Brixlegg area (Tyrol). It also includes the Sa Duchessa mine (Sardinia) but this does not contain ores of the tennantitetetrahedrite series and can be easily ruled out as an option

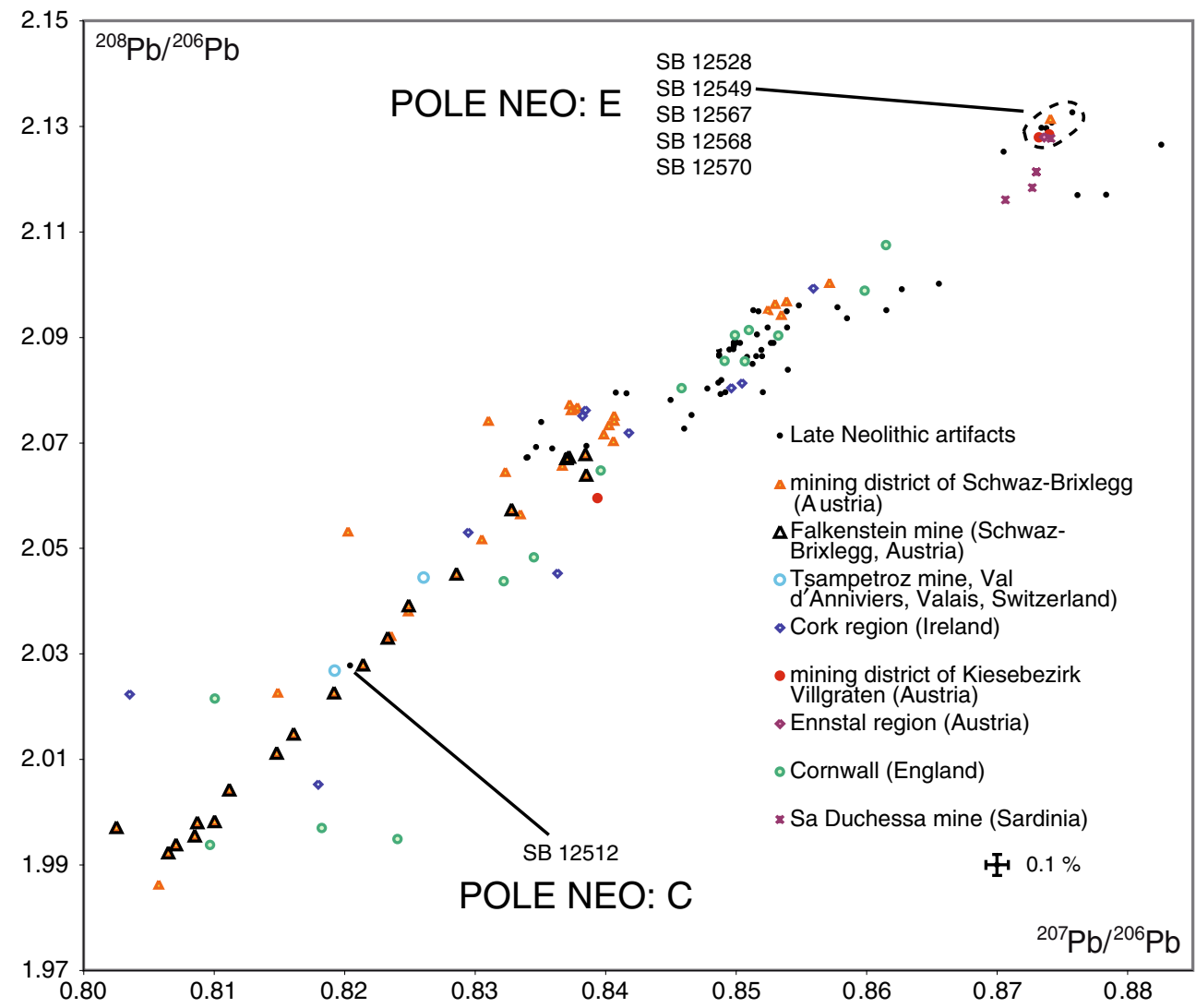


Possible provenances of the copper

Two poles were defined for the early phase and seven for the late phase, one of the poles having an unknown context. Our approach uses scatter plots to compare the composition of the metal artifacts with a database of lead isotope ratios for copper ores across Europe and Anatolia. ${ }^{2}$ This database has been separated in 17 geographic regions to make the comparison easier. There are three criteria for an ore body to be considered a possible source: first, when the lead isotope ratio of the artifact overlaps or is included in the field of the ore body's isotope ratios; second, when the chemical composition of the artifact is compatible with the mineral content of the ore body; and third, when exploitation of the ore body is chronologically possible. For the Final Neolithic, these criteria exclude Cyprus, Serbia, Wales, and Italy as possible sources.

\section{Early phase (Late Lüscherz and Early Auvernier-Cordé)}

The early phase is represented by the poles Neo: $h$ and Neo: $j$. In addition to Cyprus, Serbia, Wales, and Italy, we can also reject Turkey, Austria, Sardinia, and England as possible sources because the ore compositions do not match either pole.

\footnotetext{
${ }^{2}$ A lead isotope ratio database of ore bodies was built by compiling 3,437 published data sources that cover Europe and Anatolia, 1,143 of which come from copper minerals. Our research project (Cattin 2008) has expanded it by 80 copper mineral analyses from the Swiss Alps (73 from the Valais, three from Bern, two from Vaud, and two from the Graubünden), one analysis from Alagna Valsesia (Piemont, Italy), four analyses from Saint-Véran (Hautes-Alpes, France), and one analysis from Roua (Alpes Maritimes, France). The additional samples were taken from collections held at the Musée Cantonal de Géologie in Lausanne (N. Meisser, S. Ansermet), the Naturhistorisches Museum Bern (B. Hofmann), and H. Barge. References listed per region are Wales: Rohl (1996), Joel et al. (1997), and Rohl and Needham (1998); England: Rohl (1996) and Rohl and Needham (1998); Ireland: Rohl and Needham (1998), Kinnaird et al. (2002), and O'Brien (2004); Spain: Stos et al. (1995), Pomies et al. (1998), Hunt Ortiz (2003), and Santos Zalduegui et al. (2004); France: Marcoux (1986), Vogt (2002), Prange and Ambert (2005), and Cattin (2008); Switzerland: Zingg (1989), Guénette-Beck (2005), and Cattin (2008); Continental Italy: Stos-Gale and Gale (1992), Stos et al. (1995), Cattin (2008), and Köppel (unpublished data; Barbara Guénette-Beck 2005, personal communication); Germany: Lippolt et al. (1983), Marcoux (1986), Krahn and Baumann (1996), Gottschalk and Baumann (2001), Niederschlag et al. (2003), Durali-Müller (2005), and Fabrice Monna (2006, personal communication); Austria: von Quadt (1985), Köppel (1997), Horner et al. (1997), Kunstmann (2003), and Höppner et al. (2005); Czech Republic: Niederschlag et al. (2003), Slobodnik et al. (2008); Sardinia: Stos-Gale and Gale (1992), Stos et al. (1995), StosGale et al. (1997), and Begemann et al. (2001); Serbia: Gale et al. (1991) and Pernicka et al. (1993); Macedonia: Gale et al. (2000); Greece: Chalkias et al. (1988), Stos-Gale (1989), and Stos et al. (1996); Bulgaria: Gale et al. (1991, 2000); Cyprus: Gale et al. (1997); and Anatolia: Yener et al. (1991), Wagner et al. (1986), Sayre et al. (2001), and Wagner et al. (2003).
}

One reason we include beads SB 12537 and SB 12557 in pole Neo: $\mathrm{h}$ is their high nickel content. As a result, both $\mathrm{La}$ Sultana mine (Spain) and Crete cannot be excluded as possible sources. However, due to their extremely scattered values, neither area can be identified as the sole source. Other ore bodies have potential if we consider that ores within the same area may have been mixed, such as the ore bodies in the Val de Zinal (Valais, Switzerland) or in the Czech Republic. In regards to the former one, mixing would incorporate the Vallesian mineralizations of Bourrimonts and Laulosses that are defined by only one lead isotope analysis on copper minerals. It is unlikely, however, that the Laulosses ore body was known in prehistoric times, seeing as it was discovered during the UROMINE survey project in the 1980s (Cavalli et al. 2002). Moreover, it contains a high iron content making it less desirable as a prehistoric copper source. The latter example, the Czech Republic, involves the Kutna Horá and Horní Slavkov sulfidic copper mines (chalcopyrite and bornite). The first of these mines is a hydrothermal vein with $\mathrm{Ag}-\mathrm{Cu}-\mathrm{Zn}-\mathrm{Pb}$ and the second appears in greisens. These magmatic contexts could support the nickel values present in the artifacts.

Although a less than satisfying overlap, the values for the Ross Island western mine (Kerry, Ireland) and the Pierreville ore body in Brittany (France) are in the vicinity of pole Neo: h. We know that the Ross Island mine has been in use since twenty-fourth century BC (O'Brien 2004), which is a few centuries after the date for the two beads in question. Furthermore, the ore mined is an arsenical copper, nickel being absent. Also, the Pierreville ore body is a lead mine whose values were obtained from two galena samples. Thus, it is unlikely that either of these mines are the copper source for beads SB 12537 and SB 12557.

The final possible copper source is Siegerland, particularly the Stahlberg and Schwabengrube ore bodies that are represented by an analysis of chalcopyrite. Both mines and the beads have similar metal compositions and the mineralizations are hydrothermal veins that contain copper, nickel, and iron sulfides. The Siegerland is the eponymous area of siegenite, a nickel-cobalt sulfide $(\mathrm{Ni}, \mathrm{Co})_{3} \mathrm{~S}_{4}$.

Helical bead SB 12578 is linked to pole Neo: $\mathrm{j}$, defined as a copper with high nickel content and a mantelic component. By comparison with the database of lead isotope ratios for European copper sources, the Siegerland and Eifel mining districts (Germany), the La Sultana mine (Spain), and the Sedmochislenitsi ore body (Iskar Vratsa, northwest Bulgaria) cannot be excluded as possible sources. As already mentioned, La Sultana mine is difficult to interpret because of its six scattered analyses on chalcopyrite. The isotopic field of the Sedmochislenitsi copper and lead mine is also large, mainly with a nonmantelic 
influence. However, the German Siegerland and Eifel mining districts cannot be eliminated, even if we are unable to identify a specific ore body as a single source.

\section{Late phase (Middle and Late Auvernier-Cordé)}

The late phase is characterized by poles Neo: b, Neo: c, Neo: d, Neo: e, Neo: f, Neo: g, and Neo: i. Immediately, the Czech Republic can be rejected as a possible source, as can the Cypriot, Serbian, Welsh, and Italian areas mentioned previously.

Pole Neo: $b$, defined solely by the analysis of bead SB 12573 , does not match convincingly with any values in the ore database. Pole Neo: $\mathrm{c}$ on the other hand, consisting of bead SB 12512, has few overlaps with the ore database (Fig. 4). These include the Falkenstein-Eiblschrofen region (Schwaz-Brixlegg, Austria), the Tsampétroz mine in the Val d'Anniviers (Valais, Switzerland), Cork (Ireland), and Cornwall (England). Although the composition of the bead SB 12512 may result from a mixing of different mines from the two latter regions, their scattered values weaken this possibility. In contrast, the Schwaz-Brixlegg area, which is linked to metallurgical activities since the fifth millennium BC, would fit particularly well. The isotopic data were obtained from arsenical tetrahedrite ore bodies in Devonian dolomites. This geological background fits particularly well with the high arsenic content of the bead. However, the $>6 \%$ nickel content is not easily explained, even if its presence is reported in secondary minerals by Martinek and Sydow (2004) and Höppner et al. (2005). Tsampétroz (Valais, Switzerland), despite the minerals present (malachite, bornite, chalcopyrite), does not account for the high nickel and arsenic contents.

Pole Neo: $\mathrm{d}$ corresponds to copper smelted from ores of the tennantite-tetrahedrite series. It includes three artifacts showing a $\mathrm{Sb} / \mathrm{As}$ correlation. Pole Neo: $\mathrm{f}$, also smelted from ores of the tennantite-tetrahedrite series, contains higher levels of antimony. These two poles, when compared to the ore database, plot in an area of the graph with many potential copper sources. Turkey can be eliminated, and a number of other scattered or poorly documented isotopic fields are not convincing as possible sources. ${ }^{3}$ Among the many remaining potential sources, ${ }^{4}$ the Vallarade mine is known to have supported prehistoric mining during the time in question, and it has the highest nickel content in the Cabrières district (Prange and Ambert 2005; Michael Prange 2008, personal communication).

\footnotetext{
${ }^{3}$ This is the case of the La Sultana mine in Spain and the Cornwall, West-Cumbria, Mendips, and North Pennines districts in England.

${ }^{4}$ Z-type ore from the Harz (Germany), Klappertshardt mine and Wilhelm mine in the Eifel district (Germany), the Terra Padedda mine in Sardinia, the Les Malines region (Gard, France), and the Costabonne ore body (Pyrénées, France).
}

Pole Neo: e has a unique signature and thus has a restricted number of compatible ore bodies (Fig. 4). Austria is the only region that cannot be excluded as a source, namely the Kieserbezirk Villgraten area (Thurntaler, Tyrol), the Walchen/ Öblarn mine (Ennstal, Eisenerz, Styria, and Upper Austria), and the Schwaz-Brixlegg area (Tyrol). However, these propositions are based on a few analyzed galena samples and the one from Schwaz-Brixlegg is an outlier. In terms of elemental composition, the Walchen/Öblarn ore body (Ennstal) contains a variety of copper minerals, including those of the tennantite-tetrahedrite series, particularly stibnite (antimony sulfide; www.mindat.org, May 2008). Gold is also reported, important considering the artifacts in pole Neo: e have gold contents greater than the mean.

Pole Neo: $g$ is characterized by the central rivet of dagger blade SB 12518. The copper, which is related to ores of the tennantite-tetrahedrite series and has elevated nickel content, does not match any of the sources in the European ore database. Either the copper used to make the rivet comes from a mine yet to be sampled or it is the result of ores being mixed from one or several mines.

Pole Neo: i consists of two artifacts with a fahlore type copper, awl SB 12551 and rod SB 12594. Mineralizations with compatible lead isotope ratios either have inconsistent mineral contents (Vacheret mine, Valais, Switzerland; Küre, Turkey; Östlische Kalkalpen, Austria; La Sultana mine, Spain) or very scattered isotope fields, such as Crete and the Stubai-Ötztal area (Austria). Nevertheless, the latter area does contain copper ore bodies with minerals of the tennantite-tetrahedrite series, specifically Wörgetal in Tyrol, Austria (Vavtar 1988).

\section{Undefined phase}

Pole Neo: a groups together a copper sheet fragment (SB 12507) and an awl (SB 12517). As above, Cyprus, Serbia, Wales, and Italy can be excluded as possible source. In addition, we are able to exclude Turkey, Bulgaria, Czech Republic, Germany, Ireland, England, and Spain. Among the remaining possibilities, we can reject the Castello di Bonvei mine (Sardinia) because malachite is inconsistent with the observed arsenic, nickel, and silver contents. In contrast, the Mont-de-Vannes (Vosges, France), SchwazBrixlegg (Austria), Baicolliou (Valais, Switzerland), and Blüomattbach (Valais, Switzerland) mineralizations have geological characteristics consistent with the arsenic and nickel content of the artifacts. Also, the lead-zinc Marlou mining district (Thasos, Greece) is reported to contain arsenic (Nicolas Meisser 2008, unpublished data, personal communication). It should be emphasized that the Vallesian hypotheses are unlikely because of their scattered isotope ratios, particularly when only one value shows any affinity with the artifacts. 


\section{Discussion}

During the time period in question, there is considerable variability in the lead isotope ratios and elemental compositions of copper artifacts, suggesting the presence of complex economic relationships and multiple chaînes opératoires. The lead isotope analyses indicate diverse copper supplies and the elemental composition data tell us that a wide range of copper ores were mined.

To summarize, we believe that there is a change in copper procurement patterns between the early and late phases of the Final Neolithic. The two poles representing the early phase are characterized by copper with high nickel content. When compared to the database of European mineralizations, we can narrow down the potential copper sources to the Rhine Massif, the Czech Republic, or Bulgaria. For the late phase, however, the poles are defined by high levels of antimony, arsenic, and silver, indicating the exploitation of minerals in the tennantite-tetrahedrite series. The proposed copper sources are in Austria, the Rhine Massif, the Harz, northern Sardinia, and the south of France.

Putting the proposed copper provenances in the context of other cultural components, we are able to see how a better understanding of copper sources informs us about settlement patterns during the Final Neolithic. Formerly oriented toward the Mediterranean world during the Lüscherz period, the Three Lakes Region, Switzerland was influenced around $2700 \mathrm{BC}$ by the Corded Ware culture complex, centered in Central Germany, Poland, and the Czech Republic. At the site of Saint-Blaise/Bains des Dames, where most of the Final Neolithic corpus comes from, the ceramostratigraphy of Michel (2002) has identified the Early Auvernier-Cordé phase, marked by the incorporation of Corded Ware-type ceramic elements into the local Lüscherz-style pottery. In the following phase, the Middle Auvernier-Cordé, he notes that the repertoire of forms and Corded Ware décors influence the Lüscherz forms, identifying hybrid creations between the two systems that led to the creation of a new ceramic repertoire unique to the Auvernier-Cordé. If we relate this to the proposed copper provenances, it turns out that the metal appearing in the early phase is oriented to the east and the north. These provenances are quite likely associated with the Corded Ware influx. In this sense, the Rhine Massif would fit particularly well with the ceramic data as the provenance for the copper. From a typological perspective, a helical bead from the early phase is similar to beads associated with the Corded Ware culture complex in Germany and Austria (Neugebauer-Maresch 1994; Heyd 2000). During the late phase, the provenances show a broader diversity. In addition to the northeastern provenance, we also see indications of Mediterranean sources.
For example, the mining district of Cabrières (Hérault, France) was active during this period (Ambert 1995; Ambert et al. 2002a, b, 2005). It is possible that some of the massive biconical beads from the Saint-Blaise/Bains des Dames site came from this region, not only because the copper compositions correspond, but this type of bead is frequently found in the south of France (Arnal et al. 1974; Barge-Mahieu 1995; Mille and Bouquet 2004).

In contrast to the ceramics, the lithic industry remains more consistent throughout the Final Neolithic, continuing to reflect southern and western influxes. The west-east axis does become more dominant during the Auvernier-Cordé with the increase of long blades and daggers, paralleled by flint importation from Grand-Pressigny region (Honegger 2001). In the same way, during the Middle and Late Auvernier-Cordé, we observe an increase in the number of metal artifacts. This increase may be linked to the desire for social display due to strong competition between individuals (Honegger 2001: 190). This is a hypothesis that could partly explain the abundance of copper and flint daggers as social signs, which can be compared with the symbolism reflected in the iconography on the stelae found at PetitChasseur at Sion (Valais, Switzerland). The work of Gallay (1995) has differentiated type A stelae, which have a poor geometric decoration with the representation of metal weapons (typically daggers with triangular blades) and type B stelae, which have a rich iconography (typically showing fabrics) with common representations of bows and arrows as well as solar motifs. Type A is correlated with the Final Neolithic and type B with the Bell Beaker. While these stelae are the expression of ideology, they also reveal the importance of copper during the Final Neolithic, notably in the form of daggers. For comparison purposes, the absence of copper representations in the iconography on type B stelae may coincide with a disinterest in this metal during the Bell Beaker, which emerges from the paucity of such artifacts. Undoubtedly, studies aiming to better determine the concurrence and transfers between different raw materials, in particular copper and flint, will in the future make it possible to conduct new research and refine our understanding in the ideological spheres represented in the stelae symbolism at Petit-Chasseur at Sion (Valais, Switzerland).

\section{Conclusion}

During the Final Neolithic, two important events took place at the Saint-Blaise/Bains-des-Dames site. First is the apparent increase-the Horgen settlement has not been fully excavated - of metal artifacts during the LüscherzEarly Auvernier-Cordé phase that is linked to a direct or indirect influence of the Corded Ware culture complex. The 
proposed provenances for the copper are consistent with the geographic origin of the Corded Ware complex. Second, during the late phase, we see a greater diversity of copper sources that parallels the change in pottery styles through time.

Our next step is to examine how these changes took place at the Saint-Blaise/Bains-des-Dames settlement by narrowing our analysis to household units. Preliminary spatial analysis of the artifacts according to their metal composition is promising, showing distinctions between houses. However, the significance of these distinctions will require additional research and analysis.

Acknowledgments This research was supported by the Swiss National Science Foundation (project PP001-102710 "Le Chalcolithique européen: céramique, cuivre et histoire du peuplement") and the Fondation Ernst et Lucie Schmidheiny. The artifacts were provided by the Office et musée cantonal de Neuchâtel, Switzerland (Béat Arnold). We also want to thank Astrid Deffner for the chemical element analyses and Christian Strahm for an updated version of these data. We are grateful to Y. Bassiakos, S. StosGale, and C. Ames for their valuable comments.

\section{References}

Ambert P (1995) Les mines préhistoriques de Cabrières (Hérault): quinze ans de recherches: état de la question. Bull Soc préhist fr 92(4):499-508

Ambert P, Coularou J, Cert C, Guendon JL, Bourgarit D, Mille B, Dainat D, Houlès N, Baumes B (2002a) Le plus vieil établissement de métallurgistes de France (IIIe millénaire av. J.-C.): Péret (Hérault). C R Palevol 1:67-74

Ambert P, Guendon JL, Laroche M, Mischka D (2002b) Données nouvelles concernant le plus vieil établissement métallurgique de France: la Capitelle du Broum (District minier de CabrièresPéret, Hérault). Archéologie en Languedoc 26:45-53

Ambert P, Bouquet L, Guendon JL, Mischka D (2005) La Capitelle du Broum (district minier de Cabrières-Péret, Hérault): établissement industriel de l'aurore de la métallurgie française (3100 2400 BC). In: Ambert P, Vaquer J (eds) La première métallurgie en France et dans les pays limitrophes, [Paris], Soc préhist fr, Actes du colloque international (Carcassonne; 28-30 Septembre 2002), Soc préhist fr, mémoire 37. Société Préhistorique Française, Paris, pp 83-96

Arnal GB, Arnal J, Ambert P, Ayroles P, Bailloud G, Bocquet A, Bordreuil M, Clottes J, Combier J, Costantini G, Montjardin R, Porte JL, Thévenot JP (1974) Types de parures datées (ou présumées) du Chalcolithique et du Bronze ancien. Études Préhist 10-11:16-59

Barge-Mahieu H (1995) Les premiers objets métalliques du Chalcolithique provençal. In: Chenorkian R (ed) L'homme méditerranéen: mélanges offerts à Gabriel Camps, professeur émérite de l'Université de Provence. Publ. de l'Univ. de Provence, Aix-enProvence, pp 359-373

Begemann F, Schmitt-Strecker S, Pernicka E, Lo Schiavo F (2001) Chemical composition and lead isotopy of copper and bronze from nuragic Sardinia. Eur J Archaeol 4:43-85

Besse M (2001) L'Europe continentale, la région Rhin-Rhône et l'habitat de Derrière-le-Château (Ain, France): la céramique commune campaniforme. Ph.D. thesis, Genève
Besse M (2003) L'Europe du 3e millénaire avant notre ère: les céramiques communes au Campaniforme: études des ensembles céramiques de l'habitat de "Derrière-le-Château" à Géovreissiat et Montréal-la-Cluse (Ain, France), de la région Rhin-Rhône et de l'Europe continentale (+ CD-ROM). Cahiers d'Archéologie Romande, Lausanne. Cahiers d'Archéologie Romande 94

Brill RH, Wampler JM (1965) Isotope ratios in archaeological objects of lead. In: Application of science in the examination of works of art, Boston, Museum of Fine Arts. Proceedings of the seminar (Boston; September 7-16, 1965)

Brill RH, Wampler JM (1967) Isotope studies of ancient lead. Am J Archaeol 71(1):63-77

Cattin F (2008) Modalités d'approvisionnement et modalités de consommation du cuivre dans les Alpes au 3e millénaire avant notre ère: apport des analyses métalliques à la connaissance des peuplements du Néolithique final, du Campaniforme et du Bronze ancien. Ph.D. thesis, Genève

Cattin F (2009) Modalités d'approvisionnement et modalités de consommation du cuivre dans les Alpes au 3e millénaire avant notre ère: apport des analyses métalliques à la connaissance des peuplements du Néolithique final, du Campaniforme et du ancien. Résumé de thèse. Bull Soc préhist fr 106(2):384-385

Cattin F, Besse M (2006) Le Valais au sein des Alpes: la métallurgie du cuivre au IIIe millénaire av. J-C $\mathrm{Cu}+5: 5-8$

Cavalli D, Haldemann E, Jaffé F, Rouiller JD, Crestin D, Meisser N, Tissières P (2002) Notice explicative partielle de la Carte des ressources minérales de la Suisse, Feuille 2 (Valais, Oberland bernois). Centre de Recherche sur l'Environnement Alpin et Commission Géotechnique Suisse, Sion

Chalkias S, Vavelidis M, Schmitt-Strecker S, Begemann F (1988) Geologische Interpretation der Blei-Isotopen-Verhältnisse von Erzen der Insel Thasos, der Ägäis und Nordgriechenlands. In: Wagner GA, Weisgerber G (eds) Antike Edel- und Buntmetallgewinnung auf Thasos. Selbstverlag des Deutschen BergbauMuseums, Bochum, Der Anschnitt Beiheft 6, Veröffentlichungen aus dem Deutschen Bergbau-Museum Bochum 42. Deutschen Bergbau Museums, Bochum, pp 59-74

Deffner A (1993) Die Metallanalysen der neolithischen Siedlung von St.-Blaise, Kanton Neuchâtel. Master thesis, Institut für Ur- und Frühgeschichte, Freiburg im Breisgau

Desideri J (2007) L'Europe du 3e millénaire avant notre ère et la question du Campaniforme: histoire des peuplements par l'étude des traits non métriques dentaires. Ph.D. thesis, Genève

Durali-Müller S (2005) Roman lead and copper mining in Germany: their origin and development through time, deduced from lead and copper isotope provenance studies. Ph.D. thesis, Frankfurt am Main

Faure G (1986) Principles of isotope geology. New York, Chichester [etc.], J. Wiley, (Wiley international edition), 2nd ed

Gale NH, Stos-Gale ZA, Lilov P, Dimirov M, Todorov T (1991) Recent studies of neolithic copper ores and artefacts in Bulgaria. In: Mohen J-P, Eluère C (eds) Découverte du metal. Colloque de l'exposition "Le premier or de l'humanité en Bulgarie" (SaintGermain-en-Laye; 1989), Coll. Millénaires 2. Picard, Paris, pp 49-75

Gale NH, Stos-Gale ZA, Maliotis G, Annetts N (1997) Lead isotope data from the Isotrace Laboratory, Oxford: archaeometry data base 4, ores from Cyprus. Archaeometry 39(1):237-246

Gale NH, Stos-Gale ZA, Radouncheva A, Ivanov I, Lilov P, Todorov T, Panayotov I (2000) Early metallurgy in Bulgaria. In: Annuary of Department Archaeology, volume 4-5. New Bulgarian University, Institute of Archaeology with Museum, Bulgarian Academy of Sciences, Sofia, pp 102-168

Galer S, Abouchami W (1998) Practical application of lead triple spiking for correction of instrumental mass discrimination. Mineral magazine 62A:491-492 
Gallay A (1995) La nécropole du Petit-Chasseur à Sion et ses stèles: idéologie et contexte social. In: Gallay A (ed) Dans les Alpes à l'aube du métal: archéologie et bande dessinée. Catalogue de l'exposition "Le soleil des morts-Archéologie et bande dessinée" (Sion; 1995-1996). Musées Cantonaux du Valais, Sion, pp 103-112

Giligny F, Michel R (1995) L'évolution des céramiques de 2920 à 2440 av. J.-C. dans la région des Trois Lacs (Suisse occidentale). In: Voruz JL (ed) Chronologies néolithiques: de 6000 à 2000 avant notre ère dans le Bassin rhodanien. Actes du colloque (Ambérieu-en-Bugey; 19-20 Sept. 1992), Docum Dép d'anthrop et d'écologie de l'Université de Genève 20. Société Préhistorique Rhodanienne, Ambérieu-en-Bugey, pp 347-361

Gottschalk R, Baumann A (2001) Material provenance of late Roman lead coffins in the Rheinland, Germany. Eur J Mineral 13:197-205

Grögler N, Geiss J, Grünenfelder M, Houtermans FG (1966) Isotopenuntersuchungen zur Bestimmung der Herkunft römischer Bleirohre und Bleibarren. Z Naturforsch 21a:1167-1172

Guénette-Beck B (2005) Minerais, métaux, isotopes: recherches archéométriques sur les mines de plomb et d'argent en Valais, Suisse. Ph.D. thesis, Lausanne

Heyd V (2000) Die Spätkupferzeit in Süddeutschland. In: Saarbrücker Beiträge zur Altertumskunde 73. Habelt, Bonn

Honegger M (2001) L'industrie lithique taillée du Néolithique moyen et final de Suisse. Monographie du CRA, 24. CNRS, Paris

Höppner B, Bartelheim M, Huijsmans M, Krauss R, Martinek K, Pernicka E, Schwab R (2005) Prehistoric copper production in the Inn Valley (Austria), and the earliest copper in central Europe. Archaeometry 47(2):293-315

Horner J, Neubauer F, Paar WH, Hansmann W, Koeppel V, Robl K (1997) Structure, mineralogy, and $\mathrm{Pb}$ isotopic composition of the As-Au-Ag deposit Rotgülden, Eastern Alps (Austria): significance for formation of epigenetic ore deposits within metamorphic domes. Mineralium deposita 32:555-568

Hunt Ortiz M (2003) Prehistoric mining and metallurgy in South West Iberian Peninsula. BAR Int ser 1188. Archaeopress, Oxford

Joel EC, Taylor T, Ixer RA, Goodway M (1997) Lead isotope analysis and the Great Orme mine. In: Sinclair A, Slater E, Gowlett J (eds) Archaeological sciences 1995, Oxford. Proceedings of a conference on the application of scientific techniques to the study of archaeology (Liverpool; July 1995), Oxbow monograph 64, pp 123-131

Junghans S, Sangmeister E, Schröder M (1960) Metallanalysen kupferzeitlicher und frühbronzezeitlicher Bodenfunde aus Europa. Studien zu den Anfängen der Metallurgie 1. Gebr Mann, Berlin

Junghans S, Sangmeister E, Schröder M (1968-1974) Kupfer und Bronze in der frühen Metallzeit Europas. Studien zu den Anfängen der Metallurgie 2. Gebr Mann, Berlin

Kinnaird JA, Ixer RA, Barreiro B, Nex PAM (2002) Contrasting sources for lead in $\mathrm{Cu}$-polymetallic and $\mathrm{Zn}-\mathrm{Pb}$ mineralisation in Ireland: contraints from lead isotopes. Mineralium deposita $37: 495-511$

Köppel V (1997) Bleiisotope. In: Weber L (ed) Handbuch der Lagerstätten der Erze, Industrieminerale und Energierohstoffe Österreichs - Erläuterungen zur Metallogenetischen Karte von Österreich 1:500.000 unter Einbeziehung der Industrieminerale und Energierohstoffe. Arch Lagerst Forsch Geol B-A 19, pp 485-495

Krahn L, Baumann A (1996) Lead isotope systematics of epigenetic lead-zinc mineralization in the western part of the Rheinisches Schiefergebirge, Germany. Mineralium deposita 31:225-237

Kramers I, Tolstikhin I (1997) Two terrestrial lead isotope paradoxes, forward transport modelling, ore formation and the history of the continental crust. Chem Geol 139:75-110
Krause R (2003) Studien zur kupfer- und frühbronzezeitlichen Metallurgie zwischen Karpatenbecken und Ostsee. Vorgeschichtliche Forschung 24. M Leidorf, Rahden/Westf

Kunstmann L (2003) Archäologische und archäometallurgische Untersuchungen zum Röstprozess in der spätbronzezeitlichen Kupfermetallurgie in den Ostalpen. Master thesis, Freiberg

Lippolt HJ, Schorn U, Pidgeon RT (1983) Genetic implications of new lead isotope measurements on Schwarzwald and Upper Triassic sediment galenas. Geologische Rundschau 72: $77-104$

Marcoux E (1986) Isotopes du plomb et paragenèses métalliques, traceurs de l'histoire des gîtes minéraux. Illustration des concepts de sources, d'héritage et de régionalisme dans les gîtes français, application en recherche minière. Clermont-Ferrand (Thèse d'état), Document du BRGM 117

Martinek KP, Sydow W (2004) Frühbronzezeitliche Kupfermetallurgie im Unterinntal (Nordtirol). In: Weisgerber G, Goldenberg G (eds) Alpenkupfer-Rame delle Alpi. Int. workshop "Urgeschichtliche Kupfergewinnung im Alpenraum” (Innsbruck; 4-8 Oktober 1995), Der Anschnitt, Beiheft 17, Veröffentlichungen aus dem Deutschen Bergbau-Museum 122. Deutsches Bergbau Museum Bochum, Bochum, pp 199-211

Michel R (2002) Typologie et chronologie de la céramique néolithique: céramostratigraphie d'un habitat lacustre. Archéologie neuchâteloise 27, Saint-Blaise/Bains des Dames 3. Service et Musée Cantonal d'Archéologie, Neuchâtel

Mille B, Bouquet L (2004) Le métal au 3e millénaire avant notre ère dans le Centre-Nord de la France. Anthropologica et praehistorica 115:197-215

Neugebauer-Maresch C (1994) Endneolithikum. In: Neugebauer JW (ed) Bronzezeit in Ostösterreich. Pressehaus, Wissenschaftliche Schriftenreihe Niederösterreich 98-101. Niederösterreich, St. Polten-Wien, pp 23-48

Niederschlag E, Pernicka E, Seifert T, Bartelheim M (2003) The determination of lead isotope ratios by multiple collector ICPMS: a case study of Early Bronze Age artefacts and their possible relation with ore deposits of the Erzgebirge. Archaeometry 45:61-100

O'Brien W (2004) Ross Island: mining, metal and society in early Ireland. Bronze Age studies 6. Department of Archaeology, National University of Ireland, Galway

Ottaway BS (1982) Earliest copper artifacts of the northalpine region: their analysis and evaluation. Seminar für Urgeschichte, Bern, Schriften des Seminars für Urgeschichte der Universität Bern, Heft 7

Ottaway BS (1994) Prähistorische Archäometallurgie. Leidorf, Espelkamp

Pernicka E (1990) Gewinnung und Verbreitung der Metalle in prähistorischer Zeit. Jahrbuch des Römisch- Germanischen Zentralmuseum 37(1):21-129

Pernicka E, Begemann F, Schmitt-Strecker S (1993) Eneolithic and early Bronze age copper artefacts from the Balkans and their relation to Serbian copper ores. Praehist Z 68:1-55

Piguet M, Besse M (2009) Chronology and Bell Beaker common ware. Radiocarbon 51(2):817-830

Piguet M, Desideri J, Furestier R, Cattin F, Besse M (2007) Populations et histoire des peuplements campaniformes: chronologie céramique et anthropologie biologique. In: Besse M (ed) Sociétés néolithiques: des faits archéologiques aux fonctionnements socio-économiques. Actes du 27e colloque interrégional sur le Néolithique (Neuchâtel; 1-2 Oct. 2005), Cahiers d'Archéologie Romande 108. Cahiers d'Archéologie Romande, Lausanne, pp 249-278

Pomies C, Cocherie A, Guerrot C, Marcoux E, Lancelot J (1998) Assessment of the precision and accuracy of lead-isotope ratios measured by TIMS for geochemical applications: 
example of massive sulphide deposits (Rio Tinto, Spain). Chem Geol 144(1-2):137-149

Prange M, Ambert P (2005) Caractérisation géochimique et isotopique des minerais et des métaux base cuivre de Cabrières (Hérault). In: Ambert $\mathrm{P}$, Vaquer $\mathrm{J}$ (eds) La première métallurgie en France et dans les pays limitrophes, Actes du colloque international (Carcassonne; 28-30 Septembre 2002), Soc préhist fr, mémoire 37. Société Préhistorique Française, Paris, pp 71-81

Rohl B (1996) Lead isotope data from the Isotrace Laboratory, Oxford: Archaeometry data base 2, galena from Britain and Ireland. Archaeometry 38(1):165-180

Rohl B, Needham S (1998) The circulation of metal in the British Bronze Age: the application of lead isotope analysis. British Museum Occasional Paper 102. British Museum, London

Rychner V, Kläntschi N (1995) Arsenic, nickel et antimoine. Cahiers d'Archéologie Romande, 63-64. Cahiers d'Archéologie Romande, Lausanne

Santos Zalduegui JF, García de Madinabeitia S, Gil Ibarguchi JI, Palero F (2004) A lead isotope database: the Los PedrochesAlcudia area (Spain): implications for archaeometallurgical connections across southwestern and southeastern Iberia. Archaeometry 46(4):625-634

Sayre EV, Joel EC, Blackman MJ, Yener KA, Özbal H (2001) Stable lead isotope studies of Black Sea anatolian ore sources and related Bronze age and phrygian artefacts from nearby archaeological sites. Appendix: new Central Taurus ore data. Archaeometry 43(1):77-115

Slobodník M, Jacher-Sliwczynska K, Taylor MC, Schneider J, Dolnícek Z (2008) Plumbotectonic aspects of polymetallic vein mineralization in Paleozoic sediments and Proterozoic basement of Moravia (Czech Republic). Int J Earth Sci (Geol Rundschau) 97:1-18

Stöckli WE (1995) L'évolution du Néolithique suisse. In: Stöckli WE, Niffeler U, Gross-Klee E (eds) SPM II, Néolithique. La Suisse du Paléolithique à l'aube du Moyen-Âge: de l'homme de Néandertal à Charlemagne. Société Suisse de Préhistoire et d'Archéologie, Basel, pp 19-52

Stos ZA, Gale NH, Houghton J, Speakman R (1995) Lead isotope data from the Isotrace Laboratory, Oxford: archaeometry data base 1, ores from the western Mediterranean. Archaeometry 37 (2):407-415

Stos ZA, Gale NH, Annetts N (1996) Lead isotope data from the Isotrace Laboratory, Oxford: archaeometry data base 3, ores from the Aegean, part I. Archaeometry 38(2):381-390

Stos-Gale ZA (1989) Cycladic copper metallurgy. In: Hauptmann A, Pernicka E, Wagner GA (eds) Archäometallurgie der Alten Welt: Beiträge zum Internationalen Symposium "Old World archaeometallurgy”, Heidelberg 1987 = Old World archaeometallurgy: proceedings of the International Symposium "Old World archaeometallurgy", Heidelberg 1987. Der Anschnitt, Beiheft 7, Veröffentlichungen aus dem Deutschen Bergbau-Museum Bochum 44. Selbstverl. des Deutschen Bergbau-Museums, Bochum, pp 279-291

Stos-Gale ZA, Gale NH (1992) New light on the provenience of the copper oxhide ingots found on Sardinia. In: Tykot RH, Andrews TK (eds) Sardinia in the Mediterranean: a footprint in the sea: studies in Sardinian archaeology presented to Miriam S. Balmuth. Monographs in Mediterranean archaeology 3. Sheffield Academic, Sheffield

Stos-Gale ZA, Maliotis G, Gale NH, Annetts N (1997) Lead isotope characteristics of the Cyprus copper ore deposits applied to provenance studies of copper oxhide ingots. Archaeometry 39 (1):83-123

Strahm C (1971) Die Gliederung der Schnurkeramischen Kultur in der Schweiz. Acta Bernensia 6. Stämpfli et Cie, Bern

Strahm C (1994) Die Anfänge der Metallurgie in Mitteleuropa. Helvetia Archaeol 25(97):2-39

Vavtar F (1988) Die Erzanreicherungen im Nordtiroler Stubai-, Ötztalund Silvrettakristallin. Arch lagerst Geol B-A 9:103-153

Vogt ML (2002) Etude minéralogique et géochimique du filon à $\mathrm{Pb}-\mathrm{Zn}-$ $\mathrm{Cu}$ du Dorneloch (Steinbach, France). Master thesis, Lausanne

von Quadt A (1985) Geochronologische, geochemische und isotopengeochemische Untersuchungen an Gesteinen der Habach-Formation, der Scheelitlagerstätte und des angrenzenden Altkristallins im Felbertal (Land Salzburg). Ph.D. thesis, ETH Zürich

Wagner GA, Pernicka E, Seeliger TC, Lorenz IB, Begemann F, Schmitt-Strecker S, Eibner C, Öztunali Ö (1986) Geochemische und isotopische Charakteristika früher Rohstoffquellen für Kupfer, Blei, Silber und Gold in der Türkey. Jahrb des Römisch-Ger Zentralmus Mainz 33(2):723-752

Wagner GA, Wagner I, Öztunali Ö, Schmitt-Strecker S, Begemann F (2003) Archäometallurgischer Bericht über Feldforschung in Anatolien und bleiisotopische Studien an Erzen und Schlacken. In: Stöllner T, Körlin G, Steffens G, Cierny J (eds) Man and mining-Mensch und Bergbau: studies in honour of Gert Weisgerber on occasion of his 65th birthday, Bochum, Der Anschnitt, Beiheft 16, Veröffentlichungen aus dem Deutschen Bergbau-Museum Bochum 114. Veröffentlichungen aus dem Deutschen Bergbau-Museum Bochum, Bochum, pp 475-494

Yener KA, Sayre EV, Joel EC, Özbal H, Barnes IL, Brill RH (1991) Stable lead isotope studies of Central Taurus ore sources and related artifacts from Eastern Mediterranean Chalcolithic and Bronze age sites. J Archaeol Sci 18:541-577

Zingg M (1989) Die Siviez-Mischabel Decke: Entstehung und Entwicklung eines Altkristallins und seiner Vererzungen (Wallis, Schweiz). Ph.D. thesis, ETH Zurich 